\title{
Ekonomia społeczna jako ważne ogniwo reintegracji zawodowej osób z niepełnosprawnościami w Polsce
}

\author{
Ewa Mynarska*
}

\begin{abstract}
Streszczenie: $\quad$ Osoby niepełnosprawne są szczególnie narażone do wykluczenie społeczne i zawodowe. Trudna sytuacja osób z niepełnosprawnością na ryku pracy skłania do zmiany polityki społecznej i przybrania kierunku rozwiązań ekonomii społecznej. Z danych na temat rynku pracy osób niepełnosprawnych oraz z analizy literatury na temat działalność podmiotów ekonomii społecznej w Polsce wynika, że podmioty ekonomii społecznej nie są skutecznym narzędziem aktywizacji osób niepełnosprawnych na rynku pracy.

Słowa kluczowe: ekonomia społeczna, rynek pracy osób niepełnosprawnych, aktywizacja zawodowa.
\end{abstract}

\section{Identyfikacja problemu: rynek pracy osób z niepełnosprawnością w Polsce}

Osoby z niepełnosprawnością są szczególnie narażone na wykluczenie zawodowe, a tym samym - wykluczenie z uczestnictwa w życiu społecznym [Ratajczyk, 2005, s. 219]. To stwierdzenie jest często spotykane $w$ literaturze przedmiotu, ale równie często bywa praktycznym doświadczeniem osób niepełnosprawnych na polu zawodowym.

Analizując sytuację zawodową osób z niepełnosprawnością w Polsce nie sposób pominąć faktu, że rynek pracy, na którym funkcjonują osoby z badanej grupy, charakteryzuje się pewnego rodzaju dualnością, polegającą na współwystępowaniu otwartego rynku pracy oraz rynku pracy chronionej'. Dodatkowo wyróżnia się również tzw. rynek pracy niedostępnej, czyli obszar, w którym osoby niepeł-

Według Ewidencji Zatrudnionych Osób Niepełnosprawnych PFRON pod koniec 2017 r. było zarejestrowanych 260404 pracowników niepełnosprawnych, w tym 122094 osób pracowało na chronionym rynku pracy, a 138310 osób na otwartym rynku pracy [Biuro, 2018a, s. 19]. nosprawne prawdopodobnie nigdy nie będą zatrudnione (ze względu na dysfunkcje ich organizmu) [Garbat, 2005].

Zjawisko wykluczenia osób z niepełnosprawnościami na rynku pracy jest szczególnie zauważalne na tle aktywności ekonomicznej osób sprawnych. Z danych BAEL z 2017 r. wynika, że współczynnik aktywności zawodowej osób sprawnych w wieku produkcyjnym wynosił 79,8\%, wskaźnik zatrudnienia-75,9\%, a stopa bezrobocia - 4,9\%. Tymczasem te same wskaźniki dla osób niepełnosprawnych w wieku produkcyjnym kształtowały się odpowiednio na poziomie: $28,9 \%, 26,3 \%$ oraz $9,3 \%$ [Biuro, 2018a, s. 7].

W Polsce wśród osób niepełnosprawnych bardzo wysoki jest odsetek biernych zawodowo $(82,4 \%$ dla osób w wieku 16 lat i więcej oraz $71,1 \%$ dla osób w wieku produkcyjnym). Za główną przyczynę niepodejmowania aktywności zawodowej uważa się występującą cho-

\footnotetext{
* Ewa Mynarska

Uniwersytet Ekonomiczny w Krakowie Wydział Ekonomii i Stosunków Międzynarodowych e-mail: ewa.mynarska@wp.pl
} 
robę lub niesprawność, ale jak wskazują same osoby niepełnosprawne, przyczyną ich bierności zawodowej jest także: brak doświadczenia zawodowego i kompetencji, brak wsparcia, strach przed ośmieszeniem, natłok obowiązków, obawa przed utratą świadczenia z tytułu niezdolności do pracy oraz zniechęcenie bezskutecznością poszukiwania pracy [ibidem, s. 15-16].

Głęboko zakorzeniona w świadomości Polaków definicja osoby niepełnosprawnej - kojarzona najczęściej z modelem medycznym - w konsekwencji prowadzi do przeświadczenia, że za brak pracy osób z niepełnosprawnościami odpowiadają same osoby niepełnosprawne. Takie ujęcie uprzedmiotawia osoby niepełnosprawne i sprowadza je do kategorii osób wybrakowanych, tzn. osób z różnorodnymi brakami. Zupełnie inny obraz kreuje Konwencja o prawach osób niepełnosprawnych przyjęta przez Zgromadzenie ONZ dnia 13 grudnia 2006 r., a ratyfikowana przez Polskę 6 września $2012 r^{2}{ }^{2}$ W jej świetle braku zatrudnienia u osoby niepełnosprawnej należy upatrywać nie w samej tej osobie, ale w społeczeństwie, które ją otacza. To społeczeństwo nie jest $w$ stanie stworzyć i zagwarantować własnym obywatelom odpowiednich warunków do zaspokojenia potrzeby edukacji oraz zatrudnienia [Filek, 2018, s. 14-15].

Z licznych badań na temat zatrudniania osób niepełnosprawnych wynika, że "niepełnosprawni nie mogą skutecznie konkurować na rynku pracy z osobami w pełni sprawnymi" [Skąpski, 2006, s. 137]. Pomiędzy osobami niepełnosprawnymi a osobami sprawnymi posiadającymi identyczne kwalifikacje zawodowe, w przypadku ubiegania się o zatrudnienie na otwartym rynku pracy, występują faktyczne nierówności skutkujące wykluczeniem społeczno-zawodowym.

\section{Miejsce ekonomii społecznej w polityce społecznej $i$ jej wpływ na reintegrację zawodową osób z niepełnosprawnościami}

Reintegracyjna rola ekonomii społecznej wobec osób z niepełnosprawnościami na rynku pracy jest niejako efektem zarówno współpracy pomiędzy biznesem a ekonomią społeczną, jak i rozwoju nowego modelu polityki społecznej - aktywnej polityki społecznej.

Samo pojęcie ekonomii społecznej jest bardzo rozległe i dotyka wielu sfer życia, ale najczęściej jest ono rozumiana jako jeden ze sposobów określenia działalności gospodarczej, która łączy w sobie cele społeczne i ekonomiczne. Według definicji M. Grewińskiego ekonomia społeczna to „alternatywny w stosunku do państwowej polityki społecznej sposób rozwiązywania problemów społecznych, angażujący podmioty z rożnych sektorów w celu zapewnienia większej spójności i integracji społecznej i osiągania bardziej skutecznych rezultatów przy wykorzystaniu metod partycypacji, odpowiedzialności i aktywizacji społecznej" [Grewiński, 2009, s. 10]. W związku z powyższym uznaje się, że polityka społeczna kooperuje $z$ ekonomią społeczną ze względu na korzyści, jakie owa współpraca przynosi. W obszarze reintegracji zawodowej osób niepełnosprawnych korzyści te mają wymiar: (1) podmiotowy: koncentracja na indywidualnych potrzebach osób i grup z deficytami społecznymi (budowa kapitału ludzkiego w defaworyzowanych grupach osób niepełnosprawnych); (2) rynkowy: ukierunkowanie na stosowanie reguł ekonomicznych, finansowa samodzielność (niezależność osób niepełnosprawnych od świadczeń socjalnych); (3) aktywizacyjny: nastawienie na budzenie potencjału aktywności zawodowej wśród osób niepełnosprawnych; (4) kooperatywny: integracja osób niepełnosprawnych, poczucie wsparcia grupy (solidarność społeczna) [Boni, 2008]. 
Problematyka ekonomii społecznej odwołuje się nie tylko do sfery polityki społecznej, ale przede wszystkim do gospodarki. Ekonomia społeczna posiada wiele elementów odróżniających ją od gospodarki prywatnej i publicznej. W odróżnieniu od gospodarki prywatnej, ekonomia społeczna nie jest nastawiona na zysk podmiotów, lecz na realizację celów społecznych, w ramach których znajduje się niwelowanie wykluczenia społecznego i zawodowego [Głąbicka, 2010, s. 9]. Z punktu widzenia analizowanego tu problemu badawczego - reintegracji zawodowej osób z niepełnosprawnościami - do celów ekonomii społecznej zalicza się szczególnie: integrację społeczną; promowanie wolności i wspieranie godności ludzkiej; wzmacnianie ładu społecznego; wspomaganie jednostek, które są w szczególny sposób narażone na szkody, krzywdy i niebezpieczeństwa w skutek ich zależności ekonomicznej; poprawę społeczno-ekonomicznej pozycji większości osób; zapewnienie minimalnych standardów socjalnych; polepszenie warunków pracy i warunków życia; przeciwdziałanie i zwalczanie zjawisk patologii społecznej; oraz gwarantowanie minimum socjalnego i zaspokajanie potrzeb wyższego rzędu [ibidem].

\section{Główne podmioty ekonomii społecznej i solidarnościowej reintegrujące osoby wykluczone zawodowo i społecznie}

Na potrzeby stworzenia i przyjęcia w Polsce Krajowego Programu Rozwoju Ekonomii Społecznej ${ }^{3}$ wyróżniono pięć głównych grup podmiotów ekonomii społecznej, które obejmują:

\footnotetext{
Krajowy Program Rozwoju Ekonomii Społecznej (KPRES) jest programem rozwoju i stanowi dokument o charakterze operacyjno-wdrożeniowym, ustanowionym w celu realizacji średniookresowej Strategii Rozwoju Kraju 2020 oraz Strategii Rozwoju Kapitału Społecznego, Strategii Rozwoju Kapitału Ludzkiego, Krajowej Strategii Rozwoju Regionalnego oraz innych strategii rozwoju.
}

- przedsiębiorstwo społeczne - podmiot prowadzący działalność gospodarczą, którego celem jest: albo integracja społeczna i zawodowa osób zagrożonych wykluczeniem społecznym, albo świadczenie usług na rzecz publicznej użyteczności społecznej (przy jednoczesnej realizacji celów prozatrudnieniowych), a uzyskany zysk lub nadwyżka jest przeznaczana na wzmocnienie potencjału przedsiębiorstwa oraz na reintegrację zawodową i społeczną lub na działalność pożytku publicznego prowadzoną na rzecz społeczności lokalnej, w której działa przedsiębiorstwo;

- podmioty reintegracyjne (tj.: ZAZ, CIS, KIS, WTZ), mające na celu reintegrację społeczną i zawodową osób zagrożonych wykluczeniem społecznym, jednakże które w żadnym przypadku nie będą przedsiębiorstwami społecznymi;

- podmioty działające w sferze pożytku publicznego, które prowadzą działalność ekonomiczną i zatrudniają pracowników, ale ich aktywność nie jest oparta na ryzyku ekonomicznym;

- podmioty sfery gospodarczej, których utworzenie wiąże się z realizacją celu społecznego, bądź dla których leżący we wspólnym interesie cel społeczny stanowi rację bytu działalności komercyjnej (organizacje pozarządowe, ZAZ, spółdzielnie);

- inicjatywy o charakterze nieformalnym ${ }^{4}$ [KPRES, 2014].

Charakteryzując podmioty ekonomii społecznej, których zadaniem jest aktywizacja zawodowa osób niepełnosprawnych, zasadnie jest przedstawienie sposobu ich identyfikowania według zapisów projektu Krajowego Programu Rozwoju Ekonomii Społecznej na lata 2014-2023 opracowanego przez Mini-

\footnotetext{
4 Inicjatywy o charakterze nieformalnym to np. ruch kooperatyw spożywców, inne przedsięwzięcia działające w sferze wzajemnościowej ekonomii współdzielonej, różnorakie ruchy miejskie, lokatorskie i sąsiedzkie oraz ruchy spółdzielni uczniowskich.
} 
sterstwo Rodziny, Pracy i Polityki Społecznej ${ }^{5}$. W projekcie ustawy proponuje się koncepcję tzw. Ekonomii Solidarności Społecznej. Istotnym novum tej koncepcji jest wyodrębnienie wewnątrz ekonomii społecznej takiej grupy podmiotów, których podstawowym celem jest reintegracja społeczna i zawodowa osób zagrożonych wykluczeniem społecznym oraz rehabilitacja społeczna izawodowa osób z niepełnosprawnością [MRPiPS, 2018].

Do podzbioru podmiotów ekonomii solidarnej zaliczane są: przedsiębiorstwa społeczne; spółdzielnie socjalne, spółdzielnie pracy, spółdzielnie inwalidów oraz niewidomych, a także jednostki reintegracyjne, w tym: jednostki aktywizujące osoby z niepełnosprawnością (WTZ, ZAZ) oraz jednostki zatrudnienia socjalnego aktywizujące osoby wykluczone społecznie (CIS, KIS) [ibidem].

Pomimo, że ekonomia społeczna i solidarnościowa - jak zauważono w opisywanym projekcie - nie wpływa obecnie znacząco na gospodarkę, to z uwagi na jej zakorzenienie lokalne i obecność w wielu wspólnotach samorządowych może odegrać dużo większą rolę, niż wynika to wprost z danych statystycznych. Jak podkreśla się dalej, rezultatem ekonomii społecznej i solidarnościowej może bowiem być "wzrost poziomu kapitału społecznego, zaufania i kooperacji różnych podmiotów, w szczególności pomiędzy sektorem publicznym a społecznym, co daje podstawy dla rozwoju społecznego i gospodarczego" [ibidem, s. 11].

\section{Niedokończona emancypacja: polski model zatrudnienia chronionego}

Jak wskazano powyżej, rynek pracy osób z niepełnosprawnościami działa $w$ obszarze pracy chronionej, w którym znajdują się

Krajowy Program Rozwoju Ekonomii Społecznej na lata 20142023 nie ma jeszcze statusu dokumentu obowiązującego; obecnie możemy zapoznać się z projektem zmian KPRES, który może ulec zmianom. różne podmioty mające na celu aktywizację zawodową osoby $\mathrm{z}$ niepełnosprawnością (ZPCh, ZAZ) oraz inne jednostki świadczące usługi reintegracji społeczno-zawodowej (WTZ, CIS, KIS).

Według danych zgromadzonych w ewidencji wojewodów w grudniu 2017 r. funkcjonowało 1038 ZPCh zatrudniających 166 248 osób, z czego $77,71 \%$ stanowili pracownicy z niepełnosprawnościami [Biuro, 2018b]. Większość osób zatrudnionych w ZPCh to osoby charakteryzujące się utratą zdolności do pracy jedynie $w$ niewielkim stopniu ${ }^{6}$, co odbiega od prezentowanej w literaturze koncepcji zatrudnienia chronionego. $W$ teorii, zatrudnienie $w$ warunkach chronionych powinno obejmować tylko osoby o znacznie obniżonej zdolności do pracy, a jego kluczowym zadaniem powinna być rehabilitacja niepełnosprawnych pracowników w celu przygotowania ich do pracy na otwartym rynku pracy [Bąba, 2015, s. 150].

Równocześnie podkreśla się, że w Polsce funkcjonuje coraz mniej ZPCh, a coraz więcej osób niepełnosprawnych znajduje zatrudnienie na otwartym rynku pracy. Niewątpliwie jest to pozytywne zjawisko, aczkolwiek nie świadczy ono bynajmniej na korzyść ZPCh. Osoby z niepełnosprawnością pracują poza rynkiem pracy chronionej nie dlatego, że ZPCh skutecznie prowadzą rehabilitację zawodową pracowników z niepełnosprawnościami, lecz dlatego, że pracodawcom przestało się opłacać prowadzenie tego typu działalności.

Słabość rynku pracy chronionej widać zarówno w ZPCh, jak i w zakładach aktywno-

W 2017 r. wśród pracowników niepełnosprawnych w ZPCh $54,42 \%$ stanowiły osoby niepełnosprawne w stopniu umiarkowanym, 17,24\% - w stopniu lekkim, 5,95\% - w stopniu znacznym [Biuro, 2018b].

Zgodnie z nowelizacją ustawy o rehabilitacji zawodowej i społecznej oraz zatrudnianiu osób niepełnosprawnych z 2015 roku dotację z PFRON może dostać każdy przedsiębiorca zatrudniający osoby z niepełnosprawnością bez względu na formę prowadzonej działalności. 
ści zawodowej $(Z A Z)^{8}$. Należy podkreślić, że ta forma zatrudnienia przewidziana w polskim modelu aktywizacji zawodowej osób niepełnosprawnych ma charakter marginalny i niewystarczający. Trudno również mówić o licznych i prężnie działających jednostkach świadczących usługi reintegracji społeczno-zawodowej na rzecz osób wykluczonych ze społeczeństwa, tj. CIS, WTZ, KIS 9 .

Jak wskazują dane z 2017 r., jedynie co 4. osoba z niepełnosprawnością opuszczająca WTZ lub ZAZ była w stanie podjąć jakąkolwiek pracę ( $w$ większości przypadków było to zatrudnienie chronione). Z kolei wśród osób zagrożonych społecznie, które ukończyły zajęcia w CIS, zatrudnienie podjęło średnio 4 na 10 osób [GUS, 2017, s. 1].

Niski poziom zatrudnienia osób kończących zajęcia w CIS i KIS jest szczególnie niepokojący zważywszy na fakt, że istnieje ustawowe wsparcie tych osób w formie tzw. zatrudnienia wspieranego. Zgodnie z ustawą z dnia 13 czerwca 2003 r. o zatrudnieniu socjalnym ${ }^{10}$ osoba, której szczególnie trudno wejść lub powrócić na otwarty rynek pracy (np. długotrwale bezrobotna, niepełnosprawna, uzależniona od alkoholu lub narkotyków po zakończeniu programu psychoterapii, wychodząca z bezdomności), oraz która uczęszczała przez co najmniej pół roku na zajęcia w CIS lub KIS, na wniosek kierownika, pracownika socjalnego lub swój własny, może zostać skierowana przez powiatowy urząd pracy do pracy u pracodawcy lub w CIS.

Z przedstawionych powyżej uwag wynika, że większość osób z niepełnosprawnością pracujących na rynku pracy chronionej lub korzystających z usług jednostek reintegracji społeczno-zawodowej nie jest w stanie odnaleźć się na otwartym rynku pracy. Z tego względu trudno mówić, że rynek pracy chro-

\footnotetext{
W 2017 r. było 106 ZAZ-ów, w których pracowało 4505 osób z niepełnosprawnością [Biuro, 2018c].

9 W 2017 r. funkcjonowało 166 CIS, 715 WTZ oraz 219 KIS [GUS, 2018, s. 1].

10 T.j. Dz.U. 2016 poz. 1828.
}

nionej pozytywnie wpływa na emancypację osób niepełnosprawnych.

\section{Potencjał aktywizacji zawodowej osób z niepełnosprawnością w Polsce}

Obecnie prowadzona polityka społeczna, budząca wiele zastrzeżeń, oraz niska jakość i efektywność jednostek reintegracyjnych skłaniają do podjęcia dodatkowych działań na rzecz aktywizacji zawodowej osób z niepełnosprawnościami, które są podejmowane przez organizacje pozarządowe i ośrodki wsparcia ekonomii społecznej (OWES).

Organizacje pozarządowe działające na rzecz równouprawnienia i aktywizacji osób niepełnosprawnych na rynku pracy, z uwagi na swój oddolny i obywatelski charakter, są pewnego rodzaju reakcją społeczną na potrzeby osób z niepełnosprawnościami, których państwo nie jest w stanie zaspokoić poprzez politykę społeczną. Z kolei polityka społeczna, której zadaniem jest niesienie pomocy w osiąganiu dobrobytu wszystkich obywateli, z uwzględnieniem nierówności socjalno-ekonomicznych (czyli związanych m.in. z problemami zatrudnienia, utrzymania pracy oraz zabezpieczenia), nie jest w stanie sama sprostać tym celom bez organizacji pozarządowych. Nawet przy umacniającej się idei państwa dobrobytu lub/i państwa opiekuńczego (w którego kierunku, wydaje się, zmierzają obecne władze państwowe, a co jest sprzeczne z modelem aktywnej polityki społecznej) trudno sobie wyobrazić pełne zaspokojenie wszystkich potrzeb społecznych. Z tego względu należy z góry założyć, iż polityka społeczna nie jest w stanie sama realizować zadań mających na celu aktywizację zawodową osób z niepełnosprawnościami. W związku z tym polityka społeczna musi stymulować procesy zaradcze, samopomocowe [Podgórska-Jachnik, 2014, s. 98].

Rolą organizacji pozarządowych oprócz realizacji celów statutowych jest również włączenie się w budowę samorządności lokalnej. 
Organizacje te jako instytucje tworzone przez obywateli, pracujące na rzecz realizacji ich potrzeb, muszą mieć zapewnioną nie tylko możliwość budowania społeczności lokalnej, ale również możliwość wnoszenia swojego wkładu w prace samorządu terytorialnego [Bryski, 2006, s. 236]. Z tego względu organizacje pozarządowe stanowią niejako tkankę łączną systemu demokratycznego, pełniąc przy tym rolę pośrednika między administracją publiczną, osobą niepełnosprawną (obywatelem) a gospodarką, która rządzi się swoimi prawami ekonomicznymi.

Ponadto organizacje pozarządowe angażują się w różnego typy działania rozwijające usługi na rzecz osób z niepełnosprawnościami oraz podnoszące lokalną świadomość społeczeństwa o niepełnosprawności [Giermanowska, 2014, s. 178]. To właśnie za sprawą organizacji pozarządowych rozpowszechniana jest w Polsce m.in. koncepcja zatrudnienia wspomaganego ${ }^{11}$, która ma wspierać aktywizację zawodową osób z różnymi niepełnosprawnościami oraz innych osób zagrożonych wykluczeniem społecznym [Franczak, 2016, s. 6-7].

Potencjał organizacji pozarządowych w procesie reintegracji społeczno-zawodowej osób zniepełnosprawnością może być również wzmocniony dzięki działalności OWES, które coraz liczniej pojawiają się w Polsce.

OWES są podstawowymi instytucjami wspierającymi m.in. przedsiębiorstwa społeczne. Ich zadaniem jest udzielanie doradztwa istniejącym podmiotom ekonomii społecznej (PES) oraz prowadzenie szkoleń dla osób chcących założyć własne przedsiębiorstwo społeczne lub ekonomizować swoją organizację pozarządową. Zgodnie z standardami, OWES nie działa w celu osiągnięcia zysków, a jeśli takie posiada, to przeznacza je na cele statutowe (wg statutu usługi świadczone przez OWES muszą być związane ze wsparciem

\footnotetext{
Celem zatrudnienia wspomaganego (ang. supported employment) jest wspomaganie osób niepełnosprawnych w uzyskaniu i utrzymaniu płatnego zatrudnienia na otwartym rynku pracy przy wsparciu trenera pracy.
}

funkcjonowania PES). Ośrodki realizują usługi na rzecz PES wobec: przedsiębiorstw społecznych, podmiotów reintegracyjnych (CIS i KIS, ZAZ i WTZ), organizacji pozarządowych, podmiotów sfery gospodarczej realizujących cel społeczny (lub dla których cel społeczny - będący jednocześnie wspólnym interesem - stanowi rację bytu działalności komercyjnej). Ponadto OWES ściśle i trwale współpracują z Regionalnymi Ośrodkami Polityki Społecznej jako koordynatorami rozwijania ekonomii społecznej w danym województwie [SOWES, 2017].

OWES poprzez oferowanie usług animacji lokalnej, określenie standardów efektywności oraz realizację usług rozwoju ekonomii społecznej (m.in. zindywidualizowane wsparcie i doradztwo wykwalifikowanych doradców) nie tylko pomagają stworzyć nowe przedsiębiorstwa społeczne (przeistaczać w nie inne przedsiębiorstwa), ekonomizować organizacje lub tworzyć i wspomagać jednostki reintegracyjne, ale w konsekwencji pozwalają pozyskiwać miejsca pracy dla osób zagrożonych wykluczeniem, w tym dla osób niepełnosprawnych.

\section{Podsumowanie i wnioski}

Reintegracja osób niepełnosprawnych wykluczonych społecznie i zawodowo to wymagające innowacyjnego podejścia nowe zadanie, z który mierzy się obecnie ekonomia społeczna. W Polsce ekonomia społeczna posiada spory wachlarz możliwości w zakresie zwalczania wykluczenia społeczno-zawodowego, stąd też odgrywa ważną rolę $\mathrm{w}$ reintegracji zawodowej osób z niepełnosprawnościami. Jednakże, uwzględniając posiadane zasoby, nie realizuje w pełni zamierzonego celu.

W ZPCh często pracują osoby z niepełnosprawnością, które mogłyby być zatrudnione na otwartym rynku pracy. Z kolei ZAZ działają na zasadzie 'listka figowego', który ma zakrywać problem nieefektywnej integracji społeczno-zawodowej osób z niepełnosprawnością. 
Polski model zatrudnienia chronionego jest w swoich założeniach dobry, ale tylko w stosunku do osób, które są niepełnosprawne w stopniu najbardziej dotkliwym i ciężkim. Jednostki świadczące usługi reintegracji zawodowej sprawdzają się na pewnym etapie rozwoju ekonomii społecznej, ale potem hamują proces włączania osób z niepełnosprawnościami.

\section{Literatura}

Bąba W. (2015). Analiza i ocena polskiego systemu zatrudnienia osób z niepełnosprawnościami. Kraków: Wydawnictwo Uniwersytetu Ekonomicznego w Krakowie.

Biuro Pełnomocnika Rządu ds. Osób Niepełnosprawnych (2018a). Osoby niepełnosprawne na rynku pracy. Warszawa: MRPiPS, http://www.niepelnosprawni.gov.pl/container/niepelnosprawnosc-w-liczbach/rynek-pracy/Osoby\%20niepelnosprawne\%20 na\%20rynku\%20pracy.pdf (dostęp: 11.09.2018).

Biuro Pełnomocnika ds. Osób Niepełnosprawnych (2018b). Dane od wojewodów dotyczace zakładów pracy chronionej i stanu zatrudnienia, http:// www.niepelnosprawni.gov.pl/container/niepelnosprawnosc-w-liczbach/rynek-pracy/zpch/ZPCH-II\%20polr\%202017.xIs (dostęp: 13.09.2018).

Biuro Pełnomocnika ds. Osób Niepełnosprawnych (2018c). Dane od wojewodów dotyczące liczby zakładów aktywności zawodowej i stanu zatrudnienia, http://www.niepelnosprawni.gov.pl/container/ niepelnosprawnosc-w-liczbach/rynek-pracy/zaz/ ZAZ\%2023.04.2018.xlsx (dostęp: 15.09.2018).

Boni M. (2008). Ekonomia społeczna - nowe szanse? Gdańska Konferencja Ekonomii Społecznej, 26 czerwca, http://www.ekonomiaspoleczna.pl/files/ ekonomiaspoleczna.pl/public/gk/panele/GKES_plenarna_MBoni_ekonomia_spoleczna_nowe_szanse. pdf (dostęp: 5.12.2016).

Bryski A. (2006). Organizacje pozarzadowe wobec zatrudnienia osób niepełnosprawnych, Ułatwienie wchodzenia i powrotu osób niepełnosprawnych na rynek pracy. Warszawa: Wydawnictwo ZORON.

Filek J. (2018). „Odpowiedzialne wsparcie edukacyjne", w: M. Perdeus-Białek (red.), Odpowiedzialne wsparcie a zrównoważony rozwój. Kraków: Dział ds. Osób Niepełnosprawnych Uniwersytetu Jagiellońskiego.

Franczak M. (2016). Zatrudnienie wspomagane. Zatrudnienie wspomagane $w$ pytaniach $i$ odpowiedziach. Praktyczny przewodnik dla pracodawców, http://www.wmson.eu/media/wydawnictwa/Broszura\%20ZW\%202016.pdf (dostęp: 19.09.2018).

Garbat M. (2005). „Przełamywanie barier osób niepełnosprawnych w zatrudnieniu na przykładzie dzia-
Z powyższych względów muszą powstać nowe podmioty mające inny charakter działania, które będą aktywnie i sukcesywnie przygotowywać osoby z niepełnosprawnością do wejścia na wolny rynek pracy. Potencjał ten tkwi w organizacjach trzeciego sektora.

łań podejmowanych w nowych krajach członkowskich Unii Europejskiej", Aktywizacja Zawodowa Osób Niepetnosprawnych, nr 4, s. 81-102.

Giermanowska E. (2014). „Zatrudniając niepełnosprawnych. Dobre praktyki i uwarunkowania zmian", w: B. Gąciarz, S. Rudnicki (red.), Polscy niepełnosprawni - od kompleksowej diagnozy do nowego modelu polityki społecznej. Kraków: Wydawnictwo Akademii Górniczo-Hutnicza im. S. Staszica w Krakowie.

Grewiński M. (2009). „Ekonomia społeczna - pojęcia, uwarunkowania, dorobek międzynarodowy", w: A. Austen-Tynda (red.), Ekonomia społeczna - wybrane problemy i metody ich rozwiqzywania. Katowice: Fundacja Regionalnej Agencji Promocji Zatrudnienia.

GUS (2017). Centra integracji społecznej, kluby integracji społecznej, zakłady aktywności zawodowej i warsztaty terapii zajęciowej w 2016 r. Notka informacyjna, 13 listopada. Warszawa: GUS.

GUS (2018). Centra integracji społecznej, kluby integracji społecznej, zakłady aktywności zawodowej i warsztaty terapii zajęciowej w 2017 r. Informacja sygnalna, 21 grudnia. Warszawa: GUS.

Konwencja Organizacji Narodów Zjednoczonych z dnia 13 grudnia 2006 r. o prawach osób niepełnosprawnych, Dz.U. 2012 poz. 1169.

KPRES (2014). Krajowy Program Rozwoju Ekonomii Społecznej. Załącznik do uchwały nr 164 Rady Ministrów z dnia 12 sierpnia 2014 r. w sprawie przyjęcia programu pod nazwą "Krajowy Program Rozwoju Ekonomii Społecznej", M.P. 2016 poz. 811.

MRPiPS (2018). Krajowy Program Rozwoju Ekonomii Społecznej na lata 2014-2023. Ekonomia Solidarności Społecznej. Warszawa: MRPiPS, http://www. ekonomiaspoleczna.gov.pl/download/files/EKONOMIA\%20SPOLECZNA/aktualizacja_KPRES/Projekt_ KPRES.pdf (dostęp:19.09.2018).

Podgórska-Jachnik D. (2014). Praca socjalna z osobami z niepełnosprawnościq i z ich rodzinami. Warszawa: Centrum Rozwoju Zasobów Ludzkich.

Ratajczyk W. (2005). „Osoby niepełnosprawne a wykluczenie społeczne - bariery dostępu do pracy", w: L. Frąckiewicz (red.), Wykluczenie społeczne. Katowice: Wydawnictwo Akademii Ekonomicznej w Katowicach.

Skąpski M. (2006). Ochronna funkcja prawa pracy w gospodarce rynkowej. Kraków: ZAKAMYCZE. 
SOWES (2017). Standardy Ośrodków Wsparcia Ekonomii Społecznej. Warszawa: MRPiPS, http://www. ekonomiaspoleczna.gov.pl/download/files/AKSES/
dokumenty_do_naboru_2017_18/Standardy_ OWES_ost.pdf (dostęp: 29.09.2018).

\section{Social economy as an important element of professional reintegration of people with disabilities in Poland}

Summary: The disabled people are particularly susceptible to different forms of exclusion, both social and professional. Such troublesome situation not only triggers some changes in social politics, but also it diverts into finding new solutions in the realm of social economy. Data on the situation of disabled people on the labor market and the presented literature show that social economy entities are not an effective tool for activating disabled people in the labour market.

Keywords: social economy, labour market of disabled people, professional activation.

\section{Prawa autorskie i licencja / Copyright and License}

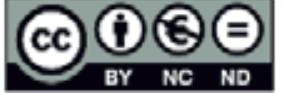

Artykuł opublikowano na licencji Creative Commons Uznanie autorstwa - Użycie niekomercyjne - Bez utworów zależnych 3.0 Polska http://creativecommons.org/licenses/by-nc-nd/3.0/pl/

This article is published under the terms of the Creative Commons Attribution - NonCommercial - NoDerivs (CC BY-NCND 3.0) License http://creativecommons.org/licenses/by-nc-nd/3.0/ 